\title{
Primary School Teachers' Metaphors on Grammar
}

\author{
Research Article
}

\section{Mehmet SOYUCOK ${ }^{1}$, Omur SADIOGLU², Esra YALCINTAS ${ }^{3}$}

${ }^{1}$ Bursa Uludag University, Faculty of Education, Department of Primary Education, Bursa, Turkey, ORCID: 0000-0001-8388-2130 ${ }^{2}$ Bursa Uludag University, Faculty of Education, Department of Primary Education, Bursa, Turkey, ORCID: 0000-0002-3055-7606 ${ }^{3}$ Bursa Uludag University, Faculty of Education, Department of Primary Education, Bursa, Turkey, ORCID: 0000-0001-6971-0519

To cite this article: Soyucok, M., \& Sadioglu, O., \& Yalcintas, E. (2020). Primary School Teachers' Metaphors on Grammar, International Online Journal of Educational Sciences, 12(3), 194-211.

\section{ARTICLE INFO}

Article History:

Received: 15.09.2019

Available online:

20.07.2020

\begin{abstract}
The purpose of this research is to determine the perceptions of primary school teachers about grammar through metaphors. The study group of the research consists of 116 primary school teachers who worked in various provinces of Turkey in the 2017-2018 academic year. The data of the research was collected through the form containing the question, "Grammar is like...........because........." that was created to gather personal information about the participants and obtain their views regarding grammar. The collected data were analysed and interpreted by content analysis technique. What primary school teachers compare grammar to, and their reasons for the comparison were grouped under various categories. As a result of the research, the categories regarding grammar were determined as follows; "grammar as the basis of language," "grammar as the right communication tool," "grammar as a set of rules," "grammar with its aesthetic aspect," "grammar with its fun aspect," "complementary/integrative grammar," "grammar as a regulator," "grammar as a tool of reflection," "grammar as a guide," "grammar with its versatility" and "grammar as a tool of change." The first three categories that contain the most metaphors are "complementary/integrative," "the basis of language" and "the right communication tool" respectively. It was determined that four primery school teachers had a negative attitude towards grammar.
\end{abstract}

(C) 2020 IOJES. All rights reserved

Keywords:

Primary school teacher, metaphor, grammar, grammar teaching

\section{Introduction}

Grammar is, besides listening, speaking, reading and writing, which are the basic skills of language, an area that refers to and covers all of these skills (Aytas and Cecen, 2010, p. 79). According to Sinanoglu (1958), grammar is the art of speaking and writing correctly. Grammar can be defined as a science which examines a

${ }^{1}$ Corresponding author's address: Bursa Uludağ Üniversitesi

Telephone: +905324309642

e-mail: msoyucok@uludag.edu.tr

DOI: https://doi.org/10.15345/iojes.2020.03.015 
language in terms of sound, shape and sentence structures and determines the rules related to them. In other words, grammar is a science that includes the dimensions of a language from sound to syllable, syllable to word, word to sentence and sentence to text, in addition to the semantic aspects of all these components (Çolak, 2013). When language is considered as a set of systems, grammar is a field of study aiming at revealing this system. Understanding of this system can be achieved by good grammar teaching (Erdem, 2007). Grammar teaching is the process of helping students sense the sound, shape and sentence structures of the language by using certain methods and carrying out activities to ensure that they use the language effectively, correctly and properly (Dolunay, 2010, p. 277).

Today, grammar subjects are taught in Turkish classes in primary schools and are not taught as a separate class. This suggests that the way teachers teach grammar subjects in Turkish classes may differ from each other. Demir and Yapıci (2007) state that one of the most important reasons why we have lagged behind developed and developing countries is the failure of mother tongue education. In this respect, it can be stated that the solution to every problem that may occur in mother tongue education should be considered carefully.

In the 2019-2020 academic year, according to the weekly primary school timetable, the 1st and 2nd grades have 10 hours of Turkish classes a week and the 3rd and 4th grades have 8 hours. Considering that there are 30 course hours in total per week in primary schools, it is seen that $33 \%$ of the time in the 1st and 2nd grades and $27 \%$ of the time in the 3rd and 4th grades are allocated to Turkish classes. Considering that the time allocated to mother tongue teaching in primary education is estimated to be $35 \%$ (Demirel, 1992) according to international standards, it can be said that the Turkish course hours in our country are inadequate in 3rd and 4th grades.

In addition to having a functional feature in solving the structure of language, grammar teaching is the most problematic area of mother tongue teaching (Çifci, 2011). Although there are many factors in this problem, factors such as failure of academicians to clarify the problems, lack of consensus in the controversial titles of the subject, not having the purposes of grammar teaching clarified and assimilated on the side of students and from the educational mentality play an important role (Çolak, 2013). In addition to this, the curricula also had an impact on the formation of the problem. For example; 1981 Turkish Basic Education Schools Turkish Education Program remained in force until 2005. Since this program was handled with a behavioral approach, the expected efficiency in language education was not achieved (Çolak, 2013). The approach in grammar teaching was made to take a backseat to the teaching basic language skills in the 2005 Primary Education Turkish Language Curriculum and Guide based on the results of PISA (Çifci, 2011). Demir and Yapici (2007) argued that grammar should be taught during the abstract operations period and that the change was a very sensible one.

Grammar teaching in primary schools aims to enable students to communicate with each other and the environment they live in by helping them gain the skills to understand and explain themselves and learn how to use their mother tongue effectively and properly. In other words, grammar teaching can be considered as an auxiliary and supportive element in the development of students' listening, speaking, reading and writing skills (Dolunay, 2010, p. 278). By means of the grammar, students discover the expressive power of language and take an important step towards achieving the goals of the language through rules. In addition, by understanding grammar, students have the opportunity to test whether or not they are making any mistakes in their expressions (Aytaş and Çeçen, 2010, p. 82).

It was mentioned above that the results of PISA lead to the impression that grammar subjects in mother tongue teaching are not sufficiently functional and based on that, in the 2005 Turkish Language Program and Guide of Primary Education, grammar teaching was pushed to the background when compared to basic skills of mother tongue (Çifci, 2011). The lack of a "Grammar" section in the 2015 and 2017 Turkish Curriculum and 
the fact that grammar subjects were taught in other learning areas shows that the same tendency has been perpetuated (Aydın and Sadioğlu, 2018).

Including grammar teaching in the scope of the Turkish course rather than considering it as a separate course on primary school level, and that the rules are not given but only touched upon with the inductive method is the mainstream approach. However, the lack of a clear information about how to use the inductive method in the program causes difficulties in the application of grammar teaching and causes problems for teachers trying to use this method (Tiryakiol, Sarıtaş and Benzer, 2018). Evidently, grammar, is the area where the least number of studies are available in terms of methods and techniques to be applied in mother tongue education and training (Çifci, 2011). In this respect, it is difficult to obtain information about how the problems experienced in grammar teaching are reflected in education. It is important to acquire knowledge about teachers' views and/or perceptions about grammar teaching in order to have information about how grammar teaching practices take place.

In recent years, there has been an increase in the use of metaphors to understand teachers' professional lives and their conceptualization of themselves in their respective experiences (Shaw and Mahlios, 2008). Metaphors, which stand out in numerous disciplines and are considered as a form of speech, a veil, a style or a pedagogical tool, are means of description that people use to explain how they see life, environment, events and objects with different images (Taverniers, 2004, p. 1; Cerit, 2008, p. 694). In metaphor, which is a major tool of perception, an allegoric information lies behind the code model transferred from a known area to an unknown area (Güveli, İpek, Atasoy and Güveli, 2011, p. 140; Liu and Lieberman, 2005, p. 306). Lakoff and Johnson (2005) explain this as understanding and experiencing one phenomenon in comparison to another. Aydin (2006) defines metaphor as a word or a set of words that are used to make the desired description of a thing or an idea without using the words "like," "similarly" in comparison with things that are nearly identical to them and while also adding stylistic beauty and ease to the narrative.

In the studies conducted on grammar teaching, problems that generally addressed are; inadequacy of teachers in grammar education and teaching (Sağır, 2002), execution of different grammar teaching practices in classes (Sever, 2000, p.27), failure of teachers to use any tools other than books, notebooks, blackboards in Turkish classes (İşcan and Kolukısa, 2005). Considering the fact that the perceptions of primary school teachers about grammar will affect their attitudes towards grammar teaching, the teaching methods, techniques and materials they use, in short, the quality of teaching in addition to the students' chance to learn grammar subjects in a permanent way, determining the metaphors primary school teachers use for grammar teaching becomes critical in the endeavor to produce solutions to teacher related problems in grammar teaching. In this study, the aim was to determine the metaphors primary school teachers use in relation to grammar.

\section{Method}

\section{Research Design}

This study was carried out using phenomenology design, which is one of the qualitative research methods. The main purpose of the phenomenological design is defining and interpreting the views of individuals on a particular subject (Yıldırım \& Şimşek, 2016, p. 69-72). In phenomenological design, metaphors are one of the data collection methods to understand the inner worlds of individuals about a certain subject, and to learn what they think and how they react to a particular event, person, phenomenon, and situations (Yıldırım \& Şimşek, 20016, p. 212). In this study, the data were evaluated by content analysis. The main purpose of content analysis is to reveal the relationships that will explain the data obtained from the study. With this analysis, similar data are brought together within the framework of certain categories or themes, and then they are organized and interpreted in a way that the reader can understand (Yıldırım and Şimşek, 2013, p. 259). 


\section{Sample / Resarch Group}

The study group of the research consists of 116 primary school teachers ( 80 females, 36 males) who worked in various provinces (45 in Marmara Region, 22 in Aegen Region, 14 in Mediterranean Region, 13 in Central Anatolian Region, 10 in Eastern Anatolian, 9 in Southern Anatolian Region and 3 in Black Sea Region) of Turkey in the 2017-2018 academic year. However, responses of 10 primary school teachers who used certain metaphors without any basis or whose metaphors and basis were incongruent, were not taken into consideration.

\section{Process / Data Collection}

In order to reveal the perceptions of the primary school teachers about "grammar," they were asked to complete the sentence; "Grammar is like because "For this purpose, the questionnaire which was used in the research was transferred to the web using Google form. The teachers were asked to focus on a single metaphor while completing the sentence and write down their thoughts. These data collected from the primary school teachers constitute the data source of the study.

\section{Data Analysis}

Validity and reliability. In this research, the metaphors and explanations formed by the participants are grouped under the categories to which they belong in order to ensure validity. The results were interpreted based on the metaphors and explanations under each category. In addition, the data analysis process is specified in all its stages.

The consistency of the research was evaluated by presenting the metaphors divided into conceptual categories to the opinions of two experts qualified in qualitative research. As a result of the experts matching the metaphors and conceptual categories, the level of concordance between the evaluation of the experts and the researcher was determined to be $93 \%$. This shows that the reliability between the encoders is high.

\section{Findings}

In this section, the metaphors formed by primary school teachers for grammar and their respective categories are presented in tables.

Table 1. Metaphors developed for "grammar" and the number and percentage of teachers representing them

\begin{tabular}{|c|c|c|c|c|c|c|c|}
\hline $\begin{array}{l}\text { Metaphor } \\
\text { code }\end{array}$ & Metaphor & $\mathbf{f}$ & $\%$ & $\begin{array}{l}\text { Metaphor } \\
\text { code }\end{array}$ & Metaphor & f & $\%$ \\
\hline 1 & Tree branches & 1 & 0,9 & 41 & Set of rules & 1 & 0,9 \\
\hline 2 & Tree & 4 & 3,8 & 42 & Pile of rules & 1 & 0,9 \\
\hline 3 & Tree body & 1 & 0,9 & 43 & Labyrinth & 1 & 0,9 \\
\hline 4 & Tree root & 2 & 1,9 & 44 & Building block of matter & 1 & 0,9 \\
\hline 5 & Mother & 2 & 1,9 & 45 & Mathematics & 3 & 2,8 \\
\hline 6 & Breast milk & 1 & 0,9 & 46 & Fruit & 1 & 0,9 \\
\hline 7 & Car & 2 & 1,9 & 47 & Non-engine parts & 1 & 0,9 \\
\hline 8 & Love & 1 & 0,9 & 48 & River & 2 & 1,9 \\
\hline 9 & Shoe & 1 & 0,9 & 49 & Oxygen & 1 & 0,9 \\
\hline 10 & Mirror & 6 & 5,7 & 50 & School & 1 & 0,9 \\
\hline 11 & Spice & 1 & 0,9 & 51 & Spine & 1 & 0,9 \\
\hline 12 & Honeycomb & 1 & 0,9 & 52 & Forest & 2 & 1,9 \\
\hline 13 & Puzzle & 2 & 1,9 & 53 & Game & 1 & 0,9 \\
\hline 14 & Sycamore & 2 & 1,9 & 54 & Spider web & 1 & 0,9 \\
\hline 15 & Flower & 2 & 1,9 & 55 & Compass & 1 & 0,9 \\
\hline 16 & Drop & 1 & 0,9 & 56 & Art & 1 & 0,9 \\
\hline 17 & Dripping tap & 1 & 0,9 & 57 & Firewood in the stove & 1 & 0,9 \\
\hline
\end{tabular}




\begin{tabular}{|c|c|c|c|c|c|c|c|}
\hline 18 & Inventory stock & 1 & 0,9 & 58 & Social life & 1 & 0,9 \\
\hline 19 & Polish of the tongue & 1 & 0,9 & 59 & Water & 1 & 0,9 \\
\hline 20 & Foundation of the house & 1 & 0,9 & 60 & Painting & 1 & 0,9 \\
\hline 21 & Young girl & 1 & 0,9 & 61 & Complementary & 1 & 0,9 \\
\hline 22 & Etiquette & 1 & 0,9 & 62 & History & 1 & 0,9 \\
\hline 23 & Invisible part & 1 & 0,9 & 63 & Scales & 1 & 0,9 \\
\hline 24 & Glasses & 1 & 0,9 & 64 & Seed & 1 & 0,9 \\
\hline 25 & Sun & 2 & 1,9 & 65 & Grilled sandwich with pepperoni & 1 & 0,9 \\
\hline 26 & Daily life & 1 & 0,9 & 66 & Traffic & 1 & 0,9 \\
\hline 27 & Life & 2 & 1,9 & 67 & Traffic signs & 2 & 1,9 \\
\hline 28 & Treasure & 1 & 0,9 & 68 & Traffic poliçe & 1 & 0,9 \\
\hline 29 & Human & 2 & 1,9 & 69 & Brick & 1 & 0,9 \\
\hline 30 & Skeleton & 1 & 0,9 & 70 & Salt & 1 & 0,9 \\
\hline 31 & Woman & 1 & 0,9 & 71 & Heart of Turkish & 1 & 0,9 \\
\hline 32 & Castle & 1 & 0,9 & 72 & The basis of Turkish & 1 & 0,9 \\
\hline 33 & Door lock & 1 & 0,9 & 73 & Building block of Turkish & 1 & 0,9 \\
\hline 34 & Snowflakes & 1 & 0,9 & 74 & Airplane & 1 & 0,9 \\
\hline 35 & Bone & 1 & 0,9 & 75 & Iron & 1 & 0,9 \\
\hline 36 & Capillary & 1 & 0,9 & 76 & Existence & 1 & 0,9 \\
\hline 37 & Dress & 2 & 1,9 & 77 & Jigsaw & 3 & 2,8 \\
\hline 38 & Book & 1 & 0,9 & 78 & Leaf & 1 & 0,9 \\
\hline 39 & Bridge & 2 & 1,9 & 79 & Law & 1 & 0,9 \\
\hline \multirow[t]{2}{*}{40} & User guide & 1 & 0,9 & 80 & Road & 1 & 0,9 \\
\hline & & & & & Total & 106 & 100 \\
\hline
\end{tabular}

As can be seen in Table 1, primary school teachers used 80 different metaphors for grammar. Each metaphor was coded. It was seen that the teachers correlated grammar with the "mirror" (6) metaphor the most. The majority of metaphors are comprised of concrete objects. Apart from this, some of the metaphors with more than one frequency (tree, tree root, mother, puzzle, plane tree, sun, human, clothing, river, forest, traffic signs) are divided into different categories due to the analogy. These differences are presented in the tables below.

Table 2. Distribution of metaphors developed for "grammar" by categories

\begin{tabular}{lll}
\hline Categories & f & \% \\
\hline Complementary/integrative grammar & 24 & 22,6 \\
Grammar as the basis of language & 19 & 17,9 \\
Grammar as the right communication tool & 18 & 7,5 \\
Grammar as a set of rules & 8 & 7,5 \\
Grammar as a tool of reflection & 6 & 5,7 \\
Grammar with its aesthetic aspect & 5 & 4,7 \\
Grammar as a tool of change & 4 & 3,8 \\
Grammar as a guide & 4 & 3,8
\end{tabular}




\begin{tabular}{llll} 
& Grammar as a regulator & 3 & \multicolumn{2}{c}{2,8} \\
\cline { 1 - 3 } Negative & Grammar as a complex structure & 3 & 2,8 \\
& Grammar as a pile of rules & 1 & 0,9 \\
\hline Total & $\mathbf{1 0 6}$ & $\mathbf{1 0 0}$ \\
\hline
\end{tabular}

As can be seen in Table 2, 11 of the categories for the metaphors are positive and two are negative categories. While only four primary school teachers' metaphors can be included in a negative category, it was determined that the remaining 102 primary school teachers have positive perceptions of grammar judging by the metaphors and explanations they've used. It was found that most of metaphors produced were in the category of "complementary/integrative grammar" with 22.6\%. Tables of each of these categories and examples included in them are presented below.

Table 3. Metaphors forming the category "complementary/integrative grammar" and the number and percentage of teachers representing them

\begin{tabular}{|c|c|c|c|}
\hline $\begin{array}{l}\text { Metaphor } \\
\text { code }\end{array}$ & Metaphor & $\mathrm{f}$ & $\%$ \\
\hline 1 & Tree branches & 1 & 0,9 \\
\hline 2 & Tree & 3 & 2,8 \\
\hline 4 & Tree root & 1 & 0,9 \\
\hline 8 & Love & 1 & 0,9 \\
\hline 11 & Spice & 1 & 0,9 \\
\hline 12 & Honeycomb & 1 & 0,9 \\
\hline 14 & Sycamore & 1 & 0,9 \\
\hline 16 & Drop & 1 & 0,9 \\
\hline 28 & Treasure & 1 & 0,9 \\
\hline 36 & Capillary & 1 & 0,9 \\
\hline 47 & Non-engine parts & 1 & 0,9 \\
\hline 50 & School & 1 & 0,9 \\
\hline 52 & Forest & 1 & 0,9 \\
\hline 54 & Spider web & 1 & 0,9 \\
\hline 58 & Social life & 1 & 0,9 \\
\hline 65 & Grilled sandwich with pepperoni & 1 & 0,9 \\
\hline 69 & Brick & 1 & 0,9 \\
\hline 70 & Salt & 1 & 0,9 \\
\hline 77 & Jigsaw & 3 & 2,8 \\
\hline \multirow[t]{2}{*}{78} & Leaf & 1 & 0,9 \\
\hline & Total & 24 & 22,6 \\
\hline
\end{tabular}

As can be seen in Table 3, the metaphors in the category of "complementary/integrative grammar" compared grammar to a "tree" (3) and a "jigsaw" (3). However, when the table is examined, metaphors like "tree branches, tree root, sycamore, forest," which are also connected with the concept of "tree," are also noteworthy. It can be said that most of the metaphors in this category concentrate on the concept of "tree." Almost one-fourth of all metaphors (22.6\%) are in this category.

Examples in the "complementary/integrative grammar" category;

T12- "Grammar is like capillaries. Because grammar covers the whole of language. Just as capillaries cover our entire body. When we talk, read poetry, we pay attention to intonation and stress, dots and commas. 
Just as we do when we write. The meaning of the sentence "old man helped the woman" and the meaning after a comma is used after "the old man" are very different. When using words, their meanings they have in our daily lives become even more beautiful with the importance of grammar and influence our relationships."

T18- "Grammar is like a grilled sandwich with pepperoni. Because maybe you can feed yourself with bread. But you'll enjoy it much more if you have pepperoni inside the toast. The use of grammar provides us with that same enjoyment."

T19- "Grammar is like social life. Because the people who make up society are like the letters that form the basis of grammar. Like letters, people should be in harmony."

T21- "Grammar is like a tree. Because just as a tree branches out, the ability to speak and write expands as one gets better at grammar."

T33- "Grammar is like a forest. Because each part of it completes a whole. The trees required for the formation of the forest each represent a rule in language. Without those rules, there can be no grammar. The narration would be left unfinished."

T38- "Grammar is like a honeycomb. Because it is knit piece by piece, step by step."

T101- "Grammar is like a treasure. Because the more knowledge you acquire, the richer you become. It introduces you to the features of your own language and you would want to get richer with it."

Table 4. Metaphors forming the category "grammar as the basis of language" and the number and percentage of teachers representing them

\begin{tabular}{llll}
\hline $\begin{array}{l}\text { Metaphor } \\
\text { code }\end{array}$ & Metaphor & f & \% \\
\hline $\mathbf{2}$ & Tree & 1 & 0,9 \\
$\mathbf{3}$ & Tree body & 1 & 0,9 \\
$\mathbf{4}$ & Tree root & 1 & 0,9 \\
$\mathbf{5}$ & Mother & 1 & 0,9 \\
$\mathbf{6}$ & Breast milk & 1 & 0,9 \\
$\mathbf{1 8}$ & Inventory stock & 1 & 0,9 \\
$\mathbf{2 0}$ & Foundation of the house & 1 & 0,9 \\
$\mathbf{3 0}$ & Skeleton & 1 & 0,9 \\
$\mathbf{3 5}$ & Bone & 1 & 0,9 \\
$\mathbf{4 4}$ & Building block of matter & 1 & 0,9 \\
$\mathbf{4 9}$ & Oxygen & 1 & 0,9 \\
$\mathbf{5 1}$ & Spine & 1 & 0,9 \\
$\mathbf{5 7}$ & Firewood in the stove & 1 & 0,9 \\
$\mathbf{5 9}$ & Water & 1 & 0,9 \\
$\mathbf{6 4}$ & Seed & 1 & 0,9 \\
$\mathbf{7 1}$ & Heart of Turkish & 1 & 0,9 \\
$\mathbf{7 2}$ & The basis of Turkish & 1 & 0,9 \\
$\mathbf{7 3}$ & Building block of Turkish & 1 & 0,9 \\
$\mathbf{7 6}$ & Existence & 1 & 0,9 \\
\hline & Total & $\mathbf{1 9}$ & $\mathbf{1 7 , 9}$ \\
\hline
\end{tabular}

As can be seen in Table 4, each of the metaphors in the category "grammar as the basis of language" were used once. However, when the table was examined, it was determined that the concepts of "tree" and "tree root are included in the previous Table 3. The "mother" metaphor is also shared in Table 6. For the metaphors in this category, the feature emphasized by teachers is that grammar is the basis of language. For this reason, "grammar as the basis of language" category was created. 
Examples of "grammar as the basis of language" category;

T37-"We can compare grammar to a tree. The extensions that emerge from the root of the tongue, the branches of the tree, are the subtitles of the subject we discuss."

T50-Grammar is like a skeleton. Because we call the structure of our language grammar. Just like our skeleton, the foundation of the human body and an inseparable whole that forms it."

T51-“Grammar is like breast milk. Because it is one of the most necessary things for a person beginning from birth."

T57-If we compare language to a plant, then grammar is the seed of a plant. Because the seed is what separates a plant from other plants, what gives it its individuality and what belongs to it. The function of grammar is to give an identity to the language to which it belongs, just like the seed."

T59- "Grammar is like the roots of the tree because it forms the basis of the language."

T97- "Grammar is like water. Just as we need water in life, we need to have knowledge of grammar to form sentences."

Table 5. Metaphors forming the category of "grammar as the right communication tool" and the number and percentage of teachers representing them

\begin{tabular}{llll}
\hline $\begin{array}{l}\text { Metaphor } \\
\text { code }\end{array}$ & Metaphor & f & \% \\
\hline $\mathbf{7}$ & Car & 2 & 1,9 \\
$\mathbf{9}$ & Shoe & 1 & 0,9 \\
$\mathbf{1 9}$ & Polish of the tongue & 1 & 0,9 \\
$\mathbf{2 5}$ & Sun & 1 & 0,9 \\
$\mathbf{2 7}$ & Life & 2 & 1,9 \\
$\mathbf{3 3}$ & Door lock & 1 & 0,9 \\
$\mathbf{3 9}$ & Bridge & 2 & 1,9 \\
$\mathbf{4 6}$ & Fruit & 1 & 0,9 \\
$\mathbf{4 8}$ & River & 1 & 0,9 \\
$\mathbf{6 1}$ & Complementary & 1 & 0,9 \\
$\mathbf{6 3}$ & Scales & 1 & 0,9 \\
$\mathbf{6 7}$ & Traffic signs & 1 & 0,9 \\
$\mathbf{7 4}$ & Airplane & 1 & 0,9 \\
$\mathbf{7 5}$ & Iron & 1 & 0,9 \\
$\mathbf{8 0}$ & Road & 1 & 0,9 \\
\hline & Total & $\mathbf{1 8}$ & $\mathbf{1 7 , 0}$ \\
\hline
\end{tabular}

Table 5 shows that 15 metaphors are formed in the category of "grammar as the right communication tool". It is seen that the metaphors of "car, life, bridge" are formed by two primary school teachers, and each of the other 12 metaphors is formed by one primary school teacher. The feature highlighted in this category of metaphors is the necessity of grammar for proper communication. For this reason, the category created was called "grammar as the correct communication tool." Among the metaphors in the table; "sun" metaphor is shown in Table 7, the "river" metaphor in Table 9 and the "traffic signs" metaphor in Table 10.

Examples of "grammar as the right communication tool" category;

T1- "Grammar is like fruit. Because it contains vitamins that facilitate communication when learned."

T23- "Grammar is like a car. Because, the car transports people from one place to another, and grammar enables communication between people." 
T52- "Grammar is like the sun. It illuminates the meaning and conveys what is wanted to be said more easily."

T54- "Grammar like a flat iron. It removes the wrinkles in expression."

T63- "Grammar is like a road. Because it brings us where we're going, to what we want to say."

T73- "Grammar is like the lock of a door. The door might open without a lock, but it's not the right way to open it."

T76- "Grammar is like a bridge. Because it is the element that makes human life easy and forms a bond between them."

Table 6. Metaphors forming the category "grammar as a set of rules" and the number and percentage of teachers representing them

\begin{tabular}{llll}
\hline $\begin{array}{l}\text { Metaphor } \\
\text { code }\end{array}$ & Metaphor & f & $\mathbf{\%}$ \\
\hline $\mathbf{5}$ & Mother & 1 & 0,9 \\
$\mathbf{2 2}$ & Etiquette & 1 & 0,9 \\
$\mathbf{2 4}$ & Glasses & 1 & 0,9 \\
$\mathbf{4 5}$ & Mathematics & 3 & 2,8 \\
$\mathbf{6 6}$ & Traffic & 1 & 0,9 \\
$\mathbf{7 9}$ & Law & 1 & 0,9 \\
\hline & Total & $\mathbf{8}$ & $\mathbf{7 , 5}$ \\
\hline
\end{tabular}

As shown in Table 6, there are six different metaphors in the "grammar as a set of rules" category. Of these, the "mathematics" metaphor is the most commonly used (three teachers) one. The feature highlighted in this category of metaphors is that the teachers see grammar as a set of unchanging rules. For this reason, this category is called "grammar as a set of rules." Among the metaphors in the table; the metaphor "mother" is also shown in Table 4 in a different category.

Examples in the "grammar as a set of rules" category;

T22- "Grammar is like etiquette. Because if one acts within the rules of etiquette while living in society, one has a superiority over oneself and the environment. Grammar is like etiquette too. The person who knows the Turkish grammar uses the language better. Life does not make sense without rules of etiquette, just as Turkish does not make sense without grammar."

T53- "Grammar is like a mother. Because just as much as we love our mother and do everything she says, grammar is like a mother for we should follow the rules she asserts in the same way."

T67- "Grammar is like math. Because it contains formulas as well."

T99- "Grammar is like the law. Because when these rules are not followed, there is a rise in mistakes in the language."

Table 7. Metaphors forming the category "grammar as a tool of reflection" and the number and percentage of teachers representing them

\begin{tabular}{llll}
\hline $\begin{array}{l}\text { Metaphor } \\
\text { code }\end{array}$ & Metaphor & f & \% \\
\hline $\mathbf{1 0}$ & Mirror & 6 & 5,7 \\
$\mathbf{2 5}$ & Sun & 1 & 1,9 \\
$\mathbf{3 2}$ & Castle & 1 & 0,9 \\
\hline & Total & $\mathbf{8}$ & $\mathbf{7 , 5}$ \\
\hline
\end{tabular}


As seen in Table 7, there are three different metaphors in the "grammar as a tool of reflection" category. Of these, the metaphor "mirror" is the most commonly used metaphor (six teachers). The feature highlighted in the metaphors in this category is that grammar reflects the language, culture and the person. For this reason, this category was called "grammar as a tool of reflection." Among the metaphors in the table; the metaphor "sun" is also included in Table 5, which belongs to a different category.

Examples of "grammar as a tool of reflection" category;

T28- "Grammar is like a mirror. Because just as when we look in the mirror, we see ourselves, we see the characteristics of our culture and language when we look at grammar."

T74- "Grammar is like a mirror. It reflects human beings."

T79- "Grammar is like the sun. The more effective and productive it is used, the better it brightens its surroundings."

Table 8. Metaphors forming the category "grammar with its aesthetic aspect" and the number and percentage of teachers representing them

\begin{tabular}{llll}
\hline $\begin{array}{l}\text { Metaphor } \\
\text { code }\end{array}$ & Metaphor & f & $\mathbf{\%}$ \\
\hline $\mathbf{1 5}$ & Flower & 2 & 1,9 \\
$\mathbf{2 1}$ & Young girl & 1 & 0,9 \\
$\mathbf{3 7}$ & Dress & 1 & 0,9 \\
$\mathbf{5 6}$ & Art & 1 & 0,9 \\
$\mathbf{6 0}$ & Painting & 1 & 0,9 \\
\hline & Total & $\mathbf{6}$ & $\mathbf{5 , 7}$ \\
\hline
\end{tabular}

As seen in Table 8, there are five different metaphors in the "grammar with aesthetic aspect" category. Of these, the metaphor "mirror" is the most commonly used metaphor (two teachers). The feature emphasized in the metaphors in this category is that grammar imparts aesthetics and beauty to the language. Therefore, this category is called "grammar with its aesthetic aspect." The metaphor "dress" in Table 8 is also found in Table 11, which belongs to a different category.

Examples of "grammar with its aesthetic aspect" category;

T9- "Grammar is like a painting. It shows its beauty when it's correct."

T25- "Grammar is like a dress. Because it is put on the language, it ornaments the language, makes it understandable and shows it as a whole."

T103- Grammar is like a flower, the more you care for it, the more beautiful it gets."

Table 9. Metaphors forming the category "grammar as a tool of change" and the number and percentage of teachers representing them

\begin{tabular}{llll}
\hline $\begin{array}{l}\text { Metaphor } \\
\text { code }\end{array}$ & Metaphor & $\mathbf{f}$ & $\mathbf{\%}$ \\
\hline $\mathbf{1 4}$ & Sycamore & 1 & 0,9 \\
$\mathbf{1 7}$ & Dripping tap & 1 & 0,9 \\
$\mathbf{2 9}$ & Human & 1 & 0,9 \\
$\mathbf{4 8}$ & River & 1 & 0,9 \\
$\mathbf{6 2}$ & History & 1 & 0,9 \\
\hline & Total & $\mathbf{5}$ & $\mathbf{4 , 7}$ \\
\hline
\end{tabular}


Table 9 shows that there are five different metaphors in the "grammar as a tool of change" category. The feature grammar that's been emphasized with metaphors in this category is that it's a tool of transfer from the past to the present, a means of renewal and development in the language. Therefore, this category is called "grammar as a tool of change." The metaphors of "sycamore", "human being" and "river" in Table 9 are also used in different categories.

Examples of "grammar as a tool of change" category;

T45- "Grammar is like a flowing river. It is like a river that renews itself, can add new materials to its structure, but always continues on its way, never stops, and loses its feature of being running water when it dries."

T72- "Grammar is like a human being. When it is developed, it develops both the people and the country."

T88- "Grammar is like history because it has a past, a present and a future."

T90- "Grammar is like a dripping tap. Because it is always fresh."

T106- "Grammar is like a hundred-years-old sycamore. Because it carries the past to the present."

Table 10. Metaphors forming the category "grammar as a guide" and the number and percentage of teachers representing them

\begin{tabular}{llll}
\hline $\begin{array}{l}\text { Metaphor } \\
\text { code }\end{array}$ & Metaphor & f & \% \\
\hline $\mathbf{4 0}$ & User guide & 1 & 0,9 \\
$\mathbf{4 1}$ & Set of rules & 1 & 0,9 \\
$\mathbf{5 5}$ & Compass & 1 & 0,9 \\
$\mathbf{6 7}$ & Traffic signs & 1 & 0,9 \\
\hline & Total & $\mathbf{4}$ & $\mathbf{3 , 8}$ \\
\hline
\end{tabular}

As shown in Table 10, there are 4 different metaphors in the "grammar as a guide" category. The feature highlighted in the metaphors in this category is that grammar is a tool that guides how the spoken language should be better used. Therefore, this category is called "grammar as a guide." The metaphor of "traffic signs" in Table 8 is also included in Table 5, which belongs to a different category.

Examples of "grammar as a guide" category;

T31- "Grammar is like a user's manual. Because people who know the language but do not know how to use it right, apply to grammar. They will have more effective language skills by learning the characteristics, subtleties and usage areas of the language together with the grammar. Just as we use the user's manual to use an item, we will use grammar in the same way for the use of a language."

T46- "Grammar is a set of rules because it shows us how to better use the language we speak through rules."

T47- "Grammar is like a compass. Because it leads us in the right direction."

T95- "Grammar is like traffic signs. Because just as traffic signs ensure the order and direction of the traffic, grammar ensures the order of language and guides us on how to use the language correctly." 
Table 11. Metaphors forming the category "grammar with its versatility" and the number and percentage of teachers representing them

\begin{tabular}{llll}
\hline $\begin{array}{l}\text { Metaphor } \\
\text { code }\end{array}$ & Metaphor & f & \% \\
\hline $\mathbf{1 3}$ & Puzzle & 1 & 0,9 \\
$\mathbf{3 4}$ & Snowflakes & 1 & 0,9 \\
$\mathbf{3 7}$ & Dress & 1 & 0,9 \\
$\mathbf{5 2}$ & Forest & 1 & 0,9 \\
\hline & Total & $\mathbf{4}$ & $\mathbf{3 , 8}$ \\
\hline
\end{tabular}

Table 11 shows that there are 4 different metaphors in the category of "grammar with its versatility" The emphasis on the metaphors in this category is on the point that there are different aspects of grammar and this leads to variety. The "puzzle" metaphor in Table 11 is also included in Table 12 which belongs to a different category, and the "dress" metaphor is also included in Table 8.

Examples in the "grammar with its versatility" category;

T2- "Grammar is like a forest. Because the more we look after it, the more we breathe."

T31- "Grammar is like a dress. Because just as various clothes differentiate and give color to the appearance of people, people in villages, towns and cities (in terms of grammar) show diversity and color in their speeches. Different mouths, different dresses..."

T48- "Grammar is like a puzzle. It leads to different ways."

T91- "Grammar is like snowflakes. Each use of grammar and each snowflake is unique."

Table 12. Metaphors forming the category "grammar with its fun aspect" and the number and percentage of teachers representing them

\begin{tabular}{llll}
\hline $\begin{array}{l}\text { Metaphor } \\
\text { code }\end{array}$ & Metaphor & $\mathbf{f}$ & $\mathbf{\%}$ \\
\hline $\mathbf{1 3}$ & Puzzle & 1 & 0,9 \\
$\mathbf{3 8}$ & Book & 1 & 0,9 \\
$\mathbf{5 3}$ & Game & 1 & 0,9 \\
\hline & Total & $\mathbf{3}$ & $\mathbf{2 , 8}$ \\
\hline
\end{tabular}

As shown in Table 12, there are three different metaphors in the "grammar with its fun aspect" category. The highlight of the metaphors in this category is the fun side of grammar. Therefore, this category is called "grammar with its fun aspect." The "puzzle" metaphor in Table 12 is also included in Table 9, which belongs to a different category.

Examples of "grammar with its fun aspect" category;

T10- "Grammar is like a game. Because you learn the rules and have a lot of fun."

T56- "Grammar is like an interesting book. Because it is very useful and enjoyable to learn and apply the rules of our language."

T89- "Grammar is like a puzzle. Because it's simple and fun..." 
Table 13. Metaphors forming the category "grammar as a regulator" and the number and percentage of teachers representing them

\begin{tabular}{llll}
\hline $\begin{array}{l}\text { Metaphor } \\
\text { code }\end{array}$ & Metaphor & $\mathbf{f}$ & $\mathbf{\%}$ \\
\hline $\mathbf{2 6}$ & Daily life & 1 & 0,9 \\
$\mathbf{3 1}$ & Woman & 1 & 0,9 \\
$\mathbf{6 8}$ & Traffic police & 1 & 0,9 \\
\hline & Total & $\mathbf{3}$ & $\mathbf{2 , 8}$ \\
\hline
\end{tabular}

Table 13 shows that there are three different metaphors in the "grammar as a regulator" category. In this category, the metaphors emphasize that the grammar is dedicated to a certain order and the words are arranged accordingly. Therefore, this category is called "grammar as a regulator."

Examples of "grammar as a regulator" category;

T13- "Grammar is like everyday life. Because it is a reflection of our daily life and behavior. We organize the words we use in our language in daily life with the help of grammar."

T24- "Grammar is like a woman. Because a woman changes the balance of the whole universe, regulates it and sets the rules."

T68- "Grammar is like traffic police because it puts words in order and makes it fluent. Grammar makes life easier and corrects any confusion."

Table 14. Metaphors forming the category "grammar as a complex structure" and the number and percentage of teachers representing them

\begin{tabular}{llll}
\hline $\begin{array}{l}\text { Metaphor } \\
\text { code }\end{array}$ & Metaphor & f & $\mathbf{\%}$ \\
\hline $\mathbf{2 3}$ & Invisible part & 1 & 0,9 \\
$\mathbf{2 9}$ & Human & 1 & 0,9 \\
$\mathbf{4 3}$ & Labyrinth & 1 & 0,9 \\
\hline & Total & $\mathbf{3}$ & $\mathbf{2 , 8}$ \\
\hline
\end{tabular}

Three of the four primary school teachers, who had negative perceptions about grammar, emphasized the complex structure of grammar. Therefore, the category of metaphors in Table 14 is called "grammar as a complex structure." The metaphor "human" in Table 14 is also included in Table 11, which belongs to a different category.

Examples of "grammar as a complex structure" category;

T3- "Grammar is like a human being. Because it's complex."

T42- "Grammar is the invisible part that lies beneath the visible surface. Because a lot meaning comes out of it. This makes it difficult to learn the language."

T43- "Grammar is like a maze. So, in answering questions, whenever I think I've solved one and then another, I disappear again. So, it's like a maze inside my brain."

Only one metaphor was included in the "grammar as a pile of rules" category, which was identified as a negative category. Since the word "pile" in the metaphor of "pile of rules" adds a negative meaning to the metaphor, it is thought that the teacher has a negative perception of grammar. The example in this category;

T83- "Grammar is like a pile of rules. Because there are so many of them." 


\section{Discussion, Conclusion and Recommendations}

In this study, perceptions of primary school teachers about grammar were determined through metaphors. When the metaphors were examined, it was determined that almost one quarter $(22.6 \%)$ of the primary school teachers considered grammar as a complementary/integrative element. The common point of metaphors in this category is that grammar stands out as a tool in terms of supporting speech, writing, and not as purpose alone. İscan (2007a) states that the aim of teaching Turkish grammar is not to teach the rules of language, but to ensure that Turkish can be used comfortably in any environment. It can be expressed that teachers who see grammar as complementary/integrative will also see grammar teaching as a tool for using language. Thus, grammar is not considered as a separate learning area in the Turkish curricula published in 2005, 2015, 2017, 2018 and 2019 and taught as a part of the other learning areas.

"Grammar as the basis of language" is the second category $(17.9 \%)$ formed by the metaphors most frequently mentioned by the primary school teachers. In this category, the emphasis was on grammar as the foundation of language and the most important element in keeping the language alive, with comparisons to "tree root, seed, breast milk, skeleton, spine, the heart of Turkish." In the description of the metaphors, it is emphasized that the most important element that makes a language what it is, is grammar. It can be thought that teachers who approach grammar with this attitude will show the necessary sensitivity to grammar teaching. As a matter of fact, in the study conducted by Aydin (1999) with secondary school teachers, it was determined that most of the teachers emphasized grammar and stated that they performed grammar exercises the most.

Language is the medium of oral and written communication between people. Karahan (2009) states that language is a system and that grammar must make sure people comprehend this system. In addition to the fact that grammar is the key to verbal and written communication, primary school teachers perceive grammar as the "right communication tool" in some of the metaphors (17\%) that they form for language knowledge and it shows that they are aware of how important grammar is in terms of communication. Similarly, Deng and Lin (2016) found in their study conducted to determine the beliefs of teachers and students about grammar, that teachers tended to teach grammar as a means of communication. In this context, it is seen that the two studies overlap. Additionally, in the study where Pilav and Elkatmış (2013) examined prospective teachers' metaphors about Turkish language they'd included the category of "Turkish as a tool of communication." When these two studies are considered together, the fact that a similar metaphor has been produced for both Turkish and grammar shows the awareness of prospective teachers and practicing teachers regarding the importance of grammar in the communicative dimension of the language. As a matter of fact, Aksan (2018) states that one of the factors that play an important role in the negative developments encountered in terms of verbal and written expression in recent years is the lack of grammar education. Therefore, it can be stated that teachers who consider grammar as the basis of language will make the necessary efforts to increase the adequacy of grammar teaching.

In the historical process grammar was first seen the art of reading and writing letters before and after that as a set of rules; nowadays, it has been expanded to become a field that examines the sound, form, sentence and text structures, and reveals the meaning and purposes of the language (Güneş, 2013). Although seeing grammar as a set of rules is an understanding from the past, it was determined that several of the teachers (7.5\%) maintained this understanding. The fact that teachers use metaphors such as mathematics, etiquette, and laws for grammar may be the reason for their use of traditional methods such as teaching and memorizing rules in their teaching methods. Deng and Lin (2016) found that although most teachers believe that inductive methods should be used in grammar teaching, they prefer deductive methods in practice. Güneş (2013) stated that there are various approaches and methods such as traditional, cognitive and constructivist in the process of education, and that the teaching of traditional grammar is followed by the order of making rules or defining, 
observing and applying examples. Research has shown that even the most successful students in the school cannot learn with a traditional grammar education (Güneş, 2013).

Six of the eight teachers who saw grammar as a means of reflection explained grammar with the metaphor "mirror". The physical property of the mirror that makes it reflect the light and the images of all living and inanimate beings, has made it a widely used metaphor in the fields of religion, literature and mythology (Ögke, 2009). In this study, the reflection feature is expressed as the reflection of grammar of the language itself, the individual and the culture of the society. In a study, Alagözlü (2009) states that the power of language to reflect the culture is not a new perspective. Alagözlü shows with various examples that proverbs and idioms also reflect the intellectual structures of individuals and societies and describe a social reality. Minimizing losses in transferring language from generation to generation will only be possible if individuals in the society use the language in the most accurate way in written and verbal communication.

In the statements formed by the teachers, there are metaphors that emphasize grammar in the way it adds aesthetics to the language (5.7\%), acts as a means of change by transferring our language from the past to the present $(4.7 \%)$, acts as a guide for the use of language $(3.8 \%)$, shows the wide range and versatility of the language $(3.8 \%)$ and has a fun and enjoyable side in the learning of it $(2.8 \%)$. In one of the studies carried out in relation to the categories created, Nerimanoğlu (2017), states that language has a function that expresses communication, thoughts and emotions and that grammar's aesthetic dimension cannot be denied. The fact that Turkish possesses an excellent richness of meaning, in which emotions, thoughts and dreams can be expressed fully and effectively, shows that its historical depth, and that it has become systematized by being processed for centuries as a scientific and literary language with a set of rules (İşcan, 2007b). In addition, İşcan (2007b) states that authors contribute to the perfection of language and that there is a relationship between the concepts of "Turkish, language and aesthetics". Accordingly, it can be stated that the metaphors of "aesthetics of language, its versatility, its being a tool of change and a guide" which are found to be reflected in teachers' perception of grammar in this study and the information in the literature overlap.

In this study, it was found that several primary school teachers $(3.7 \%)$ perceive grammar as a pile of rules. Mishra (2010) states that one of the challenges for the teacher in grammar teaching is to decide the number of rules to be taught to the students, and that at this stage, teachers should choose the grammar rules and patterns that the students use frequently in their lives. Although grammar is not included in the Turkish curriculum as a separate learning area, grammar teaching should not be neglected. Primary school teachers' understanding of grammar as a complex structure or as a pile of rules may cause them not to show the necessary sensitivity to grammar teaching in Turkish lessons. In addition, if the teachers who have a negative perception of grammar, only read the text in the course book and do the text-related activities during the Turkish class, it can prevent both teachers and students from enjoying the course. As a matter of fact Aricl (2005) found that teachers find textbooks insufficient in terms of grammar activities. In the same research, teachers stated that students were mostly interested in reading and comprehension activities in Turkish lessons, but they were not interested enough in grammar activities. For this reason, taking into account the developmental characteristics of the primary school students in the Turkish curriculum, the application examples and explanations about them will help teachers to carry out a more efficient grammar teaching process. In this way, it is thought that the perception of teachers seeing grammar as a "pile of rules" will change positively.

This study, in which primary school teachers' perceptions of grammar were determined through metaphors, shows that they are aware of the importance of grammar. In further research, it is thought that the studies on how primary school teachers' perceptions of grammar are reflected on the teaching process and how it affects the process will contribute to the literature. In addition, interviews with primary school teachers who perceive grammar as a stack of rules and observational studies in their teaching processes are considered 
to be important in determining the causes of their negative perceptions. Thus, it will be possible to conduct studies to change these perceptions positively. 


\section{REFERENCES}

Aksan, D. (2018). Türkçenin sözvarlı̆̆ı (2. Baskı). Ankara: Bilgi Yayıncılık.

Alagözlü, N. (2009). Dil ve cins: Türkçe atasözlerinde ve deyimlerde kadın üzerine eğretilemeler ve toplumbilişsel yapı. International Journal of Central Asian Studies, 13, 37-48.

Arıc1, A. F. (2005). İlköğretim okullarında dil bilgisi öğretimi üzerine öğretmen görüşleri. Atatürk Üniversitesi Kazım Karabekir Ĕ̆itim Fakültesi Dergisi, (12), 52-60.

Aydın, İ.H. (2006). Bir felsefi metafor “yolda olmak". Dinbilimleri Akademik Araştırma Dergisi, 6(4), s. 9-22.

Aydın, Ö. (1999). Orta okullarda dil bilgisi öğretimi üzerine öğretmen görüşleri. Dil Dergisi, 81, 23-29.

Aydın, Y., \& Sadioğlu, Ö. (2018). Cumhuriyet'ten Günümüze (1923-2017) ilkokul Türkçe öğretim programlarında dil bilgisi ve imla. Ana Dili Ĕ̆gitimi Dergisi, 6(4), 1091-1111.

Aytaş, G., \& Çeçen, M. A. (2010). Ana dili eğitiminde dil bilgisi öğretiminin yeri ve önemi. Türklük Bilimi Araştırmaları, 27(27), 77-89.

Cerit, Y. (2008). Öğretmen kavrami ile ilgili metaforlara ilişkin öğrenci, öğretmen ve yöneticilerin görüşleri. Türk Ĕ̆gitim Bilimleri Dergisi, 6(4), 693-712.

Çifci, M. (2011). Dil bilgisi öğretimin geleceği. 38. ICANAS (Uluslararası Asya ve Kuzey Afrika Çalışmaları Kongresi-10-15.09.2007, ANKARA) Dil Bilimi, Dil Bilgisi ve Dil Eğitimi, A. I. Cilt, 397-404.

Çolak, F. (2013). Türkçe dil bilgisi öğretiminin genel sorunları ile alan literatüründeki tartışmalı konuların ilköğretim ikinci kademe dil bilgisi öğretimine yansımaları ve çözüm önerileri (Yayınlanmamış Yüksek Lisans Tezi). Kilis 7 Aralık Üniversitesi Sosyal Bilimler Enstitüsü, Kilis.

Demir, C., \& Yapıcı, M. (2007). Ana dili olarak Türkçenin öğretimi ve sorunları. Sosyal Bilimler Dergisi, 9(2), 177-192.

Demirel, Ö. (1992). İlkokullarda Türkçe öğretimi ve sorunları. Hacettepe Üniversitesi Ĕ̆itim Fakültesi Dergisi, 8(8), 31-38.

Deng, F., \& Lin, Y. (2016). A Comparative Study on Beliefs of Grammar Teaching between High School English Teachers and Students in China. English Language Teaching, 9(8), 1-10.

Dolunay, S. K. (2010). Dil bilgisi öğretiminin amacı ve önemi. Türklük Bilimi Araştırmaları (TÜBAR)-27, 275-284.

Erdem, İ. (2007). İlköğretim II. Kademede Dil Bilgisi Öğretiminin Sorunları Üzerine Bir Araştırma (Yayınlanmamış Doktora Tezi). Gazi Üniversitesi Eğitim Bilimleri Enstitüsü, Ankara.

Güneş, F. (2013). Dil bilgisi öğretiminde yeni yaklaşımlar. Journal of Language and Literature, 2(7), 71-92.

Güveli, E., İpek, A.S., Atasoy, E., \& Güveli, H. (2011). Sınıf öğretmeni adaylarının matematik kavramına yönelik metafor alg1ları. Turkish Journal of Computer and Mathematics Education, 2(2), s. 140-159.

İşcan, A., \& Kolukısa, H. (2005). İlköğretim ikinci kademe dil bilgisi öğretiminin durumu, sorunları ve çözüm önerileri. Atatürk Üniversitesi Sosyal Bilimler Enstitüsü Dergisi, 5(1), 299-308.

İşcan, A. (2007a). İşlevsel dil bilgisinin Türkçe öğretimindeki yeri. Atatürk Üniversitesi Sosyal Bilimler Enstitüsü Dergisi, 9(1), 253-258.

İşcan, A. (2007b). Dil ve ana dil olarak Türkçe üzerine. Erciyes Dergisi, 30, 5-6.

Karadüz, A. (2014). "Dil bilgisi öğretimi", ilköğretimde Türkçe öğretimi (4. bask1) (Ed. Ahmet Kırkkılıç-Hayati Akyol) PegemA Yayıncilık, Ankara, s. 285- 318. 
Karahan, L. (2009). Dil bilgisi öğretiminde bütün-parça ilişkisinin önemi. Turkish Studies International Periodical For the Languages, Literature and History of Turkish or Turkic, 4(8), 23-30.

Lakoff, G., \& Johnson, M. (2005). Metaforlar hayat, anlam ve dil. (Çev: G. Y. Demir). İstanbul: Paradigma Yayınları.

Liu, H., \& Lieberman, H. (2005, January). Metafor: Visualizing stories as code. In Proceedings of the 10th international conference on Intelligent user interfaces (pp. 305-307). ACM.

MEB (2009). İlköğretim Türkçe dersi öğretim programı ve kılavuzu (1.-5. Sınıflar). Ankara: Devlet Kitapları Müdürlüğ̈̈̈ Basım Evi.

MEB (2017). Türkçe dersi öğretim programı (ilkokul ve Ortaokul 1, 2, 3, 4, 5, 6, 7 ve 8. Sınıflar). Ankara.

MEB (2019). Türkçe dersi öğretim programı (ilkokul ve Ortaokul 1, 2, 3, 4, 5, 6, 7 ve 8. Sınıflar). Ankara.

Mishra, P. (2010). Challenges and problems in the teaching of grammar. Language in India, 10(2), $220-231$.

Nerimanoğlu, K. V. (2017). Dil ve estetik. Akademik Tarih ve Düşünce Dergisi, 4(12), 156-184.

Ögke, A. (2009). İbnü'1-Arabî'nin Fusûsu'l-Hikem'inde ayna metaforu. Sufi Journal of Scientific E Academic Research, 23(2), 75-89.

Pilav, S., \& Elkatmış, M. (2013). Öğretmen adaylarının Türkçe kavramına ilişkin metaforları. Electronic Turkish Studies, 8(4), 1207-1220.

Sağır, M. (2002). Illköğretim okullarında Türkçe dil bilgisi öğretimi. Ankara: Nobel Yayınları.

Sever, S. (2000). Türkçe öğretimi ve tam öğrenme (3. Baskı). Ankara: Anı Yayıncılık.

Sevim, O., Veyis, F., \& Kınay, N. (2012). Öğretmen adaylarının Türkçeyle ilgili algılarının metaforlar yoluyla belirlenmesi: Atatürk Üniversitesi örneği. Cumhuriyet International Journal of Education, 1(1).

Shaw, D. M., \& Mahlios, M. (2008). Pre-service teachers' metaphors of teaching and literacy. Reading psychology, 29(1), 31-60.

Sinanoğlu, S. (1958). Dilbilgisinin önemi. Türk Dili, 81, 438-440.

Taverniers, M. (2004). Grammatical metaphors in English. Moderna Språk 98(1), 17-26.

Tiryakiol, S., Sarıtaş, H., \& Benzer, A. (2018). Kuralavarım yaklaşımıyla Türkçe dil bilgisi öğretimi. Eğitimde Nitel Araştırmalar Dergisi - Journal of Qualitative Research in Education, 6(3), $372-393$. DOI:10.14689/issn.2148-2624.1.6c3s17m

Yıldırım, A., \& Şimsek, H. (2013). Sosyal bilimlerde nitel araştırma yöntemleri (9. Baskı). Ankara: Seçkin Yayıncılık.

Yıldırım, A. \& Şimşek, H. (2016). Sosyal bilimlerde nitel araştırma yöntemleri (11. Baskı). Ankara: Seçkin Yayıncılık. 